\title{
Chemical composition, antioxidant and antitumor activities of sub-fractions of wild and cultivated Pleurotus ferulae ethanol extracts
}

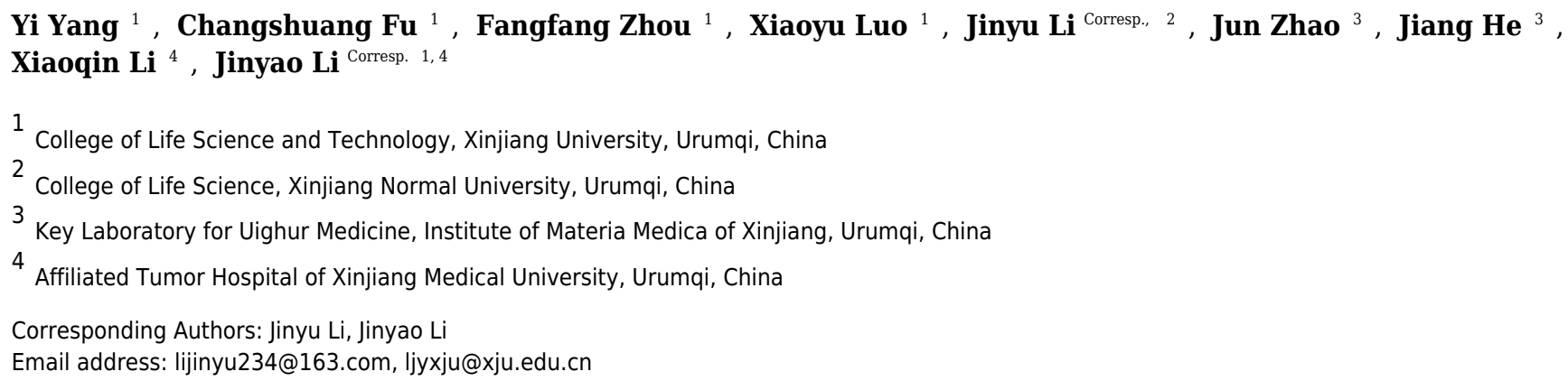

Pleurotus ferulae is an edible and medicinal mushroom with various bioactivities. Here, the ethanol extracts of wild and cultivated $P$. ferulae (PFEE-W and PFEE-C) and their subfractions including petroleum ether (Pe-W/Pe-C), ethyl acetate (Ea-W/Ea-C) and n-butanol (Ba-W/Ba-C) were prepared to evaluate their antioxidant and antitumor activities. Both PFEE-W and PFEE-C show the antioxidant activity and PFEE-W is stronger than PFEE-C. The antioxidant activities of their sub-fractions are following the order: Ea $>\mathrm{Ba}>\mathrm{Pe}$. Moreover, PFEE-W and PFEE-C significantly inhibit the proliferation of murine melanoma B16 cells, human esophageal cancer Eca-109 cells, human gastric cancer BGC823 cells and human cervical cancer HeLa cells through induction of apoptosis, which partially mediated by reactive oxygen species. The antitumor activities of their sub-fractions are following the order: $\mathrm{Ea} \geq \mathrm{Pe}>\mathrm{Ba}$. Pe-W shows higher antitumor activity compared with Pe-C, which might be correlated with the difference of their components identified by gas chromatography-mass spectrometry. These results suggest that both wild and cultivated $P$. ferulae have antioxidant and antitumor activities, and cultivated P. ferulae could be used to replace wild one in some functions. 
1 Chemical composition, antioxidant and antitumor activities of sub-fractions of wild and

2 cultivated Pleurotus ferulae ethanol extracts

3 Yi Yang ${ }^{1}$, Changshuang Fuㄹ, Fangfang Zhou ${ }^{1}$, Xiaoyu $\mathrm{Luo}^{1}$, Jinyu $\mathrm{Li}^{2 *}$, Jun Zhao ${ }^{3}$, Jiang $\mathrm{He}^{3}$,

4 Xiaoqin $\mathrm{Li}^{4}$, Jinyao $\mathrm{Li}^{1,4^{*}}$

$5{ }^{1}$ Xinjiang Key Laboratory of Biological Resources and Genetic Engineering, College of Life

6 Science and Technology, Xinjiang University, Urumqi, Xinjiang, China;

$7 \quad{ }^{2}$ College of Life Science, Xinjiang Normal University, Urumqi, Xinjiang, China;

$8{ }^{3}$ Key Laboratory for Uighur Medicine, Institute of Materia Medica of Xinjiang, Urumqi 830004, 9 China.

${ }^{4}$ Affiliated Tumor Hospital of Xinjiang Medical University, Urumqi 830011, China

*Correspondence to: Jinyao Li, Ph.D., College of Life Science and Technology, Xinjiang University, 666 Shengli Road, Urumqi, Xinjiang 830046, China. Tel.: +86-991-8583259; Fax: +86-991-8583517, e-mail: ljyxju@xju.edu.cn and Jinyu Li, Ph.D., College of Life Science, Xinjiang Normal University, 102 Xinyi Road, Urumqi, Xinjiang 830054, China. Tel.: +86-9914332474; e-mail: lijinyu234@163.com

\section{ABSTRACT}

Pleurotus ferulae is an edible and medicinal mushroom with various bioactivities. Here, the ethanol extracts of wild and cultivated P. ferulae (PFEE-W and PFEE-C) and their sub-fractions including petroleum ether (Pe-W/Pe-C), ethyl acetate (Ea-W/Ea-C) and n-butanol (Ba-W/Ba-C) were prepared to evaluate their antioxidant and antitumor activities. Both PFEE-W and PFEE-C show the antioxidant activity and PFEE-W is stronger than PFEE-C. The antioxidant activities of their sub-fractions are following the order: $\mathrm{Ea}>\mathrm{Ba}>\mathrm{Pe}$. Moreover, PFEE-W and PFEE-C significantly inhibit the proliferation of murine melanoma B16 cells, human esophageal cancer Eca-109 cells, human gastric cancer BGC823 cells and human cervical cancer HeLa cells through induction of apoptosis, which partially mediated by reactive oxygen species. The antitumor activities of their sub-fractions are following the order: $\mathrm{Ea} \geq \mathrm{Pe}>\mathrm{Ba}$. Pe-W shows 
higher antitumor activity compared with Pe-C, which might be correlated with the difference of their components identified by gas chromatography-mass spectrometry. These results suggest that both wild and cultivated $P$. ferulae have antioxidant and antitumor activities, and cultivated P. ferulae could be used to replace wild one in some functions.

\section{INTRODUCTION}

Currently, cancer is the second leading cause of death in the world. In 2015, there were 17.5 million cancer cases and 8.7 million deaths globally, which included around 4.3 million cancer cases and 2.8 million deaths in China (Chen et al. 2016; Global Burden of Disease Cancer Collaboration et al. 2017). Different strategies including surgery, chemotherapy, radiotherapy, hormone therapy, targeted therapy or their combinations have been developed to treat cancer (Chang et al. 2015; Eberhardt et al. 2015; Le Tourneau et al. 2015; Perez et al. 2014).

Medicinal fungi have various biological functions and become a hot spot in functional food and medical research. Pleurotus ferulae is an edible and medicinal mushroom which grows on the living rhizome trunks of Ferula asafoetida in the Gobi desert and mainly distributed in Xinjiang, China (Wang et al. 2014). Various biological components including fibrinolytic enzyme, lectin, pleurone and polysaccharides have been isolated from P. ferulae (Choi et al. 2017; Xu et al. 2014; Lee et al. 2011; Li et al. 2017). A growing body of research including ours has reported that $P$. ferulae extracts and some components show antioxidant, antihyperlipidemic, antitumor, anti-microbial and immunoregulatory effects (Alam et al. 2012; Choi et al. 2004; Kalyoncu et al. 2010; Li et al. 2015; Wang et al. 2014). Alam et al. (2012) have shown that the acetonic and methanolic extracts of P. ferulae exhibit better antioxidant activities than hot water extracts. Choi et al. (2004) have reported that P. ferulae ethanol extracts show stronger cytotoxicity against A549 cells than hot water extracts. Recently, we compared the antitumor activities of wild and cultivated P. ferulae ethanol extracts (PFEE-W and PFEE-C). Although PFEE-W exhibited higher antitumor activity than PFEE-C, both PFEE-C and PFEE-W 
54

55

56

significantly inhibited the growth of hepatocellular carcinoma cells through induction of apoptosis (Yang et al. 2018). Due to the source of wild P. ferulae is scarce, it has been successfully domesticated by Xinjiang Institute of soil biological desert in 1990. However, it need further investigate whether wild and cultivated $P$. ferulae have similar or different antioxidant activities and antitumor effects on different types of tumors.

In the present study, PFEE-W and PFEE-C were prepared and their major components were analyzed. PFEE-W and PFEE-C were further extracted by petroleum ether, ethyl acetate and nbutanol to collect the corresponding sub-fractions and named as Pe-W/Pe-C, Ea-W/Ea-C and BaW/Ba-C, which antioxidant and anti-tumor activities were evaluated. Then the fatty acid compositions of $\mathrm{Pe}-\mathrm{W} / \mathrm{Pe}-\mathrm{C}$ were identified by gas chromatography-mass spectrometry (GCMS). We found that PFEE-W and PFEE-C and their sub-fractions possessed antioxidant activity and could inhibit the proliferation of tumor cells through induction of cell apoptosis and necrosis..

\section{MATERIAL AND METHODS}

\section{Preparation of wild and cultivated $P$. ferulae extractions}

Cultivated and wild P. ferulae were collected from Jinghe in Xinjiang Uygur Autonomous Region, China. Wild and cultivated P. ferulae ethanol extracts (PFEE-W and PFEE-C) were prepared according to our previous protocol (Yang et al. 2018). The stepwise extractions of PFEE-W and PFEE-C were performed using petroleum ether, ethyl acetate and n-butanol orderly to obtain 6 sub-fractions and named as $\mathrm{Pe}-\mathrm{W} / \mathrm{Pe}-\mathrm{C}, \mathrm{Ea}-\mathrm{W} / \mathrm{Ea}-\mathrm{C}$ and $\mathrm{Ba}-\mathrm{W} / \mathrm{Ba}-\mathrm{C}$, respectively. These sub-fractions were concentrated using a rotary vacuum evaporator at $45{ }^{\circ} \mathrm{C}$. After air drying to remove the solvents, the 6 sub-fractions were dissolved in 100\% dimethyl sulfoxide (DMSO) (Sigma, MO, USA) at the concentration of $100 \mathrm{mg} / \mathrm{ml}$ and sterilized with a $0.22 \mu \mathrm{m}$ filter.

\section{Determination of polysaccharide content}

The polysaccharide contents of PFEE-W/C or sub-fractions were determined using the phenolsulfuric acid method according to previous protocol (Dubois et al. 1956). The optical density (OD) was measured at $490 \mathrm{~nm}$ using a 96-well microplate reader (Bio-Rad Laboratories, CA, 
80

81

82

83

84

85

86

87

88

89

90

91

92

93

USA). The polysaccharide content was calculated according to the standard curve made by the standard of glucose.

\section{Determination of polyphenol content}

The polyphenol contents of PFEE-W/C or sub-fractions were determined by ferrous tartrate method ( $\mathrm{Yu}$ et al. 2007). The OD was measured at $540 \mathrm{~nm}$ using a 96-well microplate reader. The polyphenol content was calculated according to the standard curve made by the standard of gallic acid.

\section{Determination of total flavonoid content}

The flavonoid contents of PFEE-W/C or sub-fractions were detected according to previous description (Swamy et al. 2015). The OD was detected at $517 \mathrm{~nm}$ using a 96-well microplate reader. The content of flavonoids was calculated according to the standard curve obtained by the standard of rutin.

\section{Diphenylpicrylhydrazyl (DPPH) radical scavenging assay}

DPPH radical scavenging assay was carried out according to previously described (Molyneux 2004). Briefly, PFEE-W/C or sub-fractions were dissolved in ethanol and mixed with $0.1 \mathrm{mM}$ DPPH. The ascorbic acid was used as positive control and the mixture of ethanol and DPPH was used as negative control. The OD was measured at $517 \mathrm{~nm}$ using a microplate reader. Tests were carried out in triplicate. The percentage of DPPH radical scavenging was calculated according to the equation:

DPPH radical scavenging $(\%)=\left(1-\frac{A s-A c}{A b}\right) \times 100 \%$

$A_{s}$ is the OD of the sample mixed with DPPH, $A_{c}$ is the OD of sample without DPPH and $A_{b}$ is the OD of the ethanol mixed with DPPH.

\section{Reducing Power}

The reducing activities of PFEE-W/C or sub-fractions were carried out according to previous description (Yildirim et al. 2001). The ascorbic acid was used as positive control. The OD was measured at $700 \mathrm{~nm}$.

\section{Cell lines and cell culture}


107 Murine melanoma B16 cells, human esophageal cancer Eca-109 cells, human gastric cancer 108 BGC823 cells, human cervical cancer HeLa cells and mouse liver NCTC1469 cells were 109 obtained from the Xinjiang Key Laboratory of Biological Resources and Genetic Engineering in 110 Xinjiang University (Urumqi, Xinjiang, China) and cultured in RPMI 1640 medium (Gibco) 111 supplemented with 10\% heat-inactivated fetal bovine serum (MRC), $100 \mathrm{U} / \mathrm{ml}$ penicillin and 100 $112 \mu \mathrm{g} / \mathrm{ml}$ streptomycin at $37^{\circ} \mathrm{C}$ in a humidified environment with $5 \% \mathrm{CO}_{2}$.

\section{MTT assay}

114 MTT [3-(4,5-dimethyl-2-thiazolyl)-2,5-diphenyl-2-H-tetrazolium bromide] (Sigma) assay was used to evaluate the effects of PFEE-W/C and sub-fractions on the proliferation of tumor cells. The tumor cells at the logarithmic phase of growth were seeded in 96-well plates at a density of $5 \times 10^{3}$ cells/well and cultured overnight, then treated with $\mathrm{PFEE}-\mathrm{W} / \mathrm{C}$ or sub-fractions at various concentrations $(0,100,200,400,600 \mu \mathrm{g} / \mathrm{ml})$ or $0.6 \%$ DMSO (equal to that in $600 \mu \mathrm{g} / \mathrm{ml}$ ) for 24 h. Cisplatin was used as a positive control. After centrifugation at $1200 \mathrm{rpm}$ for $7 \mathrm{~min}$, supernatant was discarded and $100 \mu \mathrm{l}$ of MTT solution $(0.5 \mathrm{mg} / \mathrm{ml}$ in PBS $)$ was added into each well and incubated at $37^{\circ} \mathrm{C}$ for $4 \mathrm{~h}$. The formed formazan crystals were dissolved in $150 \mu \mathrm{l}$ DMSO. The OD490 values were measured by a 96-well microplate reader. The relative cell viability was calculated as the followed formula: Cell viability $(\%)=\left(\mathrm{OD}_{\text {treated }} / \mathrm{OD}_{\text {untreated }}\right)$ $\times 100 \%$.

\section{Analysis of cell apoptosis}

HeLa cells were treated with PFEE-W/C and sub-fractions at concentration of $400 \mu \mathrm{g} / \mathrm{ml}$ or $0.4 \%$ DMSO for $24 \mathrm{~h}$. Cells were collected and stained with Annexin V-FITC/propidiumidide (PI) Apoptosis Detection Kit (YEASEN, China) according to the manufacturer's instructions. In some experiments, cells were pretreated with $10 \mathrm{mM} \mathrm{N}$-acetyl-L-cysteine (NAC, Sigma) for $2 \mathrm{~h}$, and treated with $400 \mu \mathrm{g} / \mathrm{ml} \mathrm{Ea-W}$ or Ea-C for $24 \mathrm{~h}$ to detect the apoptosis. Samples were analyzed by flow cytometry (BD FACSCalibur, USA).

\section{Hoechst 33342 staining}

133 After treatment with $400 \mu \mathrm{g} / \mathrm{ml}$ PFEE-W/C and sub-fractions or $0.4 \%$ DMSO for $24 \mathrm{~h}$, HeLa 
134

135

136

137

138

139

140

141

142

143

144

145

146

147

148

149

150

151

152

153

154

155

156

157

158

159

160

cells were washed with PBS and fixed with $4 \%$ ice-cold paraformaldehyde at $4{ }^{\circ} \mathrm{C}$ for $10 \mathrm{~min}$. Then cells were stained with Hoechst 33342 (Beyotime, China) at $4{ }^{\circ} \mathrm{C}$ for $10 \mathrm{~min}$ in the dark after washing with PBS. Samples were observed by inverted fluorescence microscope (Nikon Eclipse Ti-E, Japan).

\section{Measurement of reactive oxygen species (ROS)}

Intracellular ROS production was measured using DCFH-DA probes. HeLa cells were treated with $400 \mu \mathrm{g} / \mathrm{ml} \mathrm{Ea-W/Ea-C} \mathrm{or} 0.4 \%$ DMSO for $24 \mathrm{~h}$. After treatment, all cells were harvested and stained by $10 \mathrm{mM}$ of fluorescent probe DCFH-DA (Beyotime, China) for $20 \mathrm{~min}$ at $37{ }^{\circ} \mathrm{C}$. After washing three times with PBS, the fluorescence intensity in cells was determined by flow cytometry.

\section{Gas chromatography-mass spectrometry (GC-MS)}

The samples were prepared according to the following procedure. Briefly, $50 \mathrm{mg} \mathrm{Pe}-\mathrm{W} / \mathrm{Pe}-\mathrm{C}$ were mixed with $1 \mathrm{ml}$ methanol and $50 \mu \mathrm{l}$ concentrated sulfuric acid, followed by reflux for $4 \mathrm{~h}$. After cooling, saturated $\mathrm{NaCl}$ solution was add to terminate the reaction. Then, the solution was extracted with $2 \mathrm{ml} \mathrm{n}$-hexane, and the upper layer was collected for GC-MS analysis. The methyl derivatives of fatty acids were identified by a 7890A-5975C gas chromatograph equipped with a PE-5MS capillary column $(30 \mathrm{~m} \times 0.25 \mathrm{~mm} \times 0.25 \mu \mathrm{m})$. Helium (flow rate, $1.0 \mathrm{ml} / \mathrm{min}$ ) was used as the carrier gas. The column temperature was maintained initially at $100^{\circ} \mathrm{C}$ for $1 \mathrm{~min}$, followed by increasing to $200{ }^{\circ} \mathrm{C}$ at a rate of $3{ }^{\circ} \mathrm{C} / \mathrm{min}$, from $200{ }^{\circ} \mathrm{C}$ to $250{ }^{\circ} \mathrm{C}$ at a rate of $5{ }^{\circ} \mathrm{C} / \mathrm{min}$, and then kept at $250{ }^{\circ} \mathrm{C}$ for $30 \mathrm{~min}$. The electron impact energy was $70 \mathrm{eV}$ and the ion source temperature was $230^{\circ} \mathrm{C}$. Split ratio was 50:1. Electron impact (EI) mass spectra were recorded in the 33-450 amu range at $1 \mathrm{~s}$ intervals. The library search was carried out using NIST GC-MS libraries.

\section{Statistical Analysis}

We expressed all data as mean \pm standard error of the mean (SEM). Statistical analysis was performed by GraphPad Prism 5.0, and conducted with one-way analysis of variance (ANOVA). The two-tailed paired $t$ test was used to compare PFEE-W and PFEE-C and their sub-fractions. $P$ 
$161<0.05$ was considered to be statistically significant.

162

163

164

165

166

167

168

169

170

171

172

173

174

175

176

177

178

179

180

181

182

183

184

185

186

\section{RESULTS}

\section{The polysaccharide, polyphenol and flavonoid contents of PFEE-W and PFEE-C and sub-} fractions

PFEE-W/C and sub-fractions were prepared to analyze the contents of polysaccharides, polyphenols and flavonoids. Compared with PFEE-C, PFEE-W contained higher concentration of flavonoids (1.202 VS $1.04 \mathrm{mg} / \mathrm{ml})$, lower concentration of polysaccharides (38.46 VS 54.87 $\mathrm{mg} / \mathrm{ml}$ ) and similar concentration of polyphenols (Table 1). The polysaccharide and polyphenol contents in Pe-W are lower than that in Pe-C, while the flavonoid contents in Pe-W and Pe-C are similar. Ea-W and Ea-C contain similar polysaccharide contents but Ea-W contains higher concents of polyphenols and flavonoids than that of Ea-C. Same as Ea-W/Ea-C, Ba-W and Ba-C also contain similar polysaccharide contents, while $\mathrm{Ba}-\mathrm{W}$ contains higher contents of polyphenols and flavonoids than that of $\mathrm{Ba}-\mathrm{C}$.

\section{Antioxidant activities of PFEE-W/C and sub-fractions}

The antioxidant activities of PFEE-W/C and sub-fractions were measured by DPPH radical scavenging assay. As shown in Fig. 1A, all fractions showed remarkable radical scavenging activities in a dose-dependent manner. Generally, the radical scavenging activities of fractions from wild $P$. ferulae are higher than that of cultivated $P$. ferulae. The scavenging activity of ethyl acetate fraction was higher than those of petroleum ether and n-butanol fractions both in wild and cultivated P. ferulae. However, the scavenging activities of PFEE-W/C and subfractions were lower than that of $\mathrm{Vc}$, a positive control, which reached the $100 \%$ scavenging rate at $1 \mathrm{mg} / \mathrm{ml}$.

The antioxidant activities of all fractions were further evaluated by reducing power. Similarly, all fractions showed reducing power in a dose-dependent manner, and Vc showed higher reducing power than that of PFEE-W/C and sub-fractions (Fig. 1B). The reducing power of fractions from wild P. ferulae is slightly higher than that of cultivated P. ferulae. In addition, 
187 the reducing power of fractions from both wild and cultivated $P$. ferulae followed the order: $188 \mathrm{PFEE}>\mathrm{Ea} \geq \mathrm{Ba}>\mathrm{Pe}$. These results indicate that PFEE-W/C and sub-fractions have antioxidant 189 activities.

190 PFEE-W/C and sub-fractions suppress the growth of tumor cells

191 The antitumor effect of PFEE-W/C and sub-fractions was detected and compared by MTT assay.

192

193

194

195

196

197

198

199

200

201

202

203

204

205

206

207

208

209

210

211

212

213 B16, Eca-109, BGC823 and HeLa cells were treated with different concentrations of PFEE-W/C and sub-fractions for $24 \mathrm{~h}$. As shown in Fig. 2, PFEE-W/C and sub-fractions significantly reduced the viability of B16, Eca-109 and HeLa cells in a dose-dependent manner except BGC823 cells that were not sensitive. PFEE-W and PFEE-C showed similar antitumor activities against B16 and Eca-109 cells but the antitumor activity of PFEE-W was higher than that of PFEE-C for HeLa cells. Furthermore, sub-fractions from wild and cultivated $P$. ferulae showed different antitumor activities. For Eca-109 and HeLa cells, Pe-W and Ea-W exhibited higher antitumor activities than that of $\mathrm{Pe}-\mathrm{C}$ and Ea-C, respectively. The antitumor activities of subfractions from both wild and cultivated P. ferulae followed the order: Ea $\geq \mathrm{Pe}>\mathrm{Ba}$. These results indicate that PFEE-W/C and sub-fractions have antitumor activities.

We also detected the cytotoxicity of PFEE-W/C and sub-fractions on mouse liver NCTC1469 cells. Generally, the low concentrations of PFEE-W/C and sub-fractions showed no cytotoxicity, while the high concentrations of PFEE-W/C and sub-fractions significantly reduced the viability of NCTC1469 cells (supplementary Fig.1). However, the cytotoxicity of PFEE-W/C and sub-fractions on NCTC1469 cells was much lower than that on tumor cells, suggesting that PFEE-W/C and sub-fractions have minor side effect on normal cells.

\section{Chemical composition of fatty acids of Pe-W and Pe-C}

In order to find out the components caused the different antitumor activities, $\mathrm{Pe}-\mathrm{W}$ and $\mathrm{Pe}-\mathrm{C}$ were selected to do GC-MS due to their much difference of antitumor activities. The fatty acid compositions of the two sub-fractions were identified by GC-MS (supplementary Fig.2). Twenty-one components were identified in Pe-W (Table 2), which mainly contained methyl linoleate (60.95\%), hexadecanoic acid methyl ester (10.44\%), 11-Octadecenoic acid methyl ester 
214 (6.95\%) and hexadecanoic acid (4.1\%). Twenty-five components were identified in Pe-C (Table

215 2), which mainly contained methyl linoleate (58.25\%), methyl oleate (15.23\%), hexadecanoic 216 acid methyl ester $(14.32 \%)$ and myo-inositol hexaacetate (6.15\%). Compared the major 217 constituents in $\mathrm{Pe}-\mathrm{W}$ and $\mathrm{Pe}-\mathrm{C}$, the contents of methyl linoleate and hexadecanoic acid methyl

218

219

220

221

222

223

224

225

226

227

228

229

230

231

232

233

234

235

236

237

238

239

240

ester are similar but the contents of 11-octadecenoic acid methyl ester and methyl stearate are different. Except the quantitative differences of some components, the qualitative differences were also found between Pe-W and Pe-C. Some components including hexadecanoic acid, 12methyl-E,E-2,13-octadecadien-1-ol, desmosterol, ergosterol were found in Pe-W but not in Pe-C. Other components including methyl oleate and myo-inositol hexaacetate were found in Pe-C but not in Pe-W. The difference of components might cause the different antitumor activities of Pe$\mathrm{W}$ and Pe-C.

\section{PFEE-W/C and sub-fractions induce apoptosis of HeLa cells}

To investigate whether PFEE-W/C and sub-fractions can induce apoptosis of tumor cells, HeLa cells were selected and treated with $400 \mu \mathrm{g} / \mathrm{ml}$ of PFEE-W/C, Pe-W/C and Ea-W/C for $24 \mathrm{~h}$. After Annexin V-FITC and PI staining, cell apoptosis was analyzed by flow cytometry. Compared with untreated group, the frequencies of apoptotic and necrotic HeLa cells were significantly increased after PFEE-W/C, Pe-W/C and Ea-W/C treatment, but these extracts mainly induced apoptosis $(>60 \%)$ compared with necrosis $(<20 \%)$ (Fig. 3A). PFEE-W and PFEE-C have similar activities in the induction of apoptosis and necrosis. Pe-W and Ea-W show higher activities than Pe-C and Ea-C, respectively, in the induction of apoptosis and necrosis. Furthermore, Hoechst 33342 staining was used to observe the morphology of nuclei of HeLa cells upon PFEE-W/C and sub-fractions treatment. As shown in Fig. 3B, the nuclei of untreated cells were homogeneously stained, but the nuclei of PFEE-W/C and sub-fractions treated cells showed condensed and fragmented. These results indicated that PFEE-W/C and sub-fractions induced apoptosis of HeLa cells.

ROS partially mediates the induction of apoptosis by Ea-W and Ea-C

ROS plays an important role in the induction of apoptosis (Redza-Dutordoir \& Averill-Bates 
241 2016). Due to the high antitumor activity, Ea-W and Ea-C were selected to investigate the role of

242 ROS in the induction of apoptosis. After treatment for $24 \mathrm{~h}$, Hela cells were stained with the

243 specific fluorescence probe DCFH-DA to detect intracellular ROS levels. As shown in Fig. 4A, 244 ROS production showed dynamically changes upon Ea-W and Ea-C treatment. ROS production

245 was significantly increased at $2 \mathrm{~h}$ and gradually decreased from $8 \mathrm{~h}$ to $24 \mathrm{~h}$, then dramatically 246 increased at $48 \mathrm{~h}$.

247 Next, NAC, a ROS scavenger, was used to test the role of ROS in the induction of apoptosis. 248 As shown in Fig. 4B, NAC pretreatment partially inhibited the apoptosis of HeLa cells induced 249 by Ea-W and Ea-C, suggesting that ROS produced during the first $2 \mathrm{~h}$ promoted the induction of 250 apoptosis.

\section{DISCUSSION}

252 Several studies including ours have been reported that $P$. ferulae contains a number of active 253 components such as polysaccharides, flavonoids and polyphenols, and exhibits antioxidant, antitumor, antihyperglycemic and immunoregulatory activities (Choi et al. 2016; Choi et al. 2004; Alam et al. 2012, Li et al. 2015; Li et al. 2017; Wang et al. 2014). However, cultivated P. ferulae has been used in almost studies including ours due to the resource of wild $P$. ferulae is scarce. It is still elusive whether wild and cultivated P. ferulae have similar or different activities of antioxidation and antitumor. Here, the ethanol extracts of wild and cultivated $P$. ferulae and their sub-fractions were prepared to compare their components and antioxidant and antitumor activities. The results show that PFEE-C contains higher concentration of polysaccharides and lower concentration of flavonoids than PFEE-W. The contents of polyphenols are similar in PFEE-W and PFEE-C. The contents of these components are different in their sub-fractions. Generally, PFEE-W/C and their sub-fractions show strong antioxidant and antitumor activities. Compared with PFEE-C and its sub-fractions, PFEE-W and its some sub-fractions showed higher antioxidant and antitumor activities to a certain extent, which might be correlated with the differences of their components. 
Due to the much difference of antitumor activities between $\mathrm{Pe}-\mathrm{W}$ and $\mathrm{Pe}-\mathrm{C}$, the

268

269

270

271

272

273

274

275

276

277

278

279

280

281

282

283

284

285

286

287

288

289

290

291

292

293

components of Pe-W and Pe-C were identified by GC-MS. We found that the predominant constituents in Pe-W and Pe-C were methyl linoleate (60.95\% VS 58.25\%) and hexadecanoic acid methyl ester (10.44\% VS 14.32\%). Linoleic acid and its methyl esters have many beneficial effects in the prevention of atherosclerosis, cancer, hypertension and improvement of immune function (Whelan. 2008; Bhattacharya et al. 2006). It has been reported that linoleic acid or conjugated linoleic acid can inhibit the proliferation of hybridoma cells or human breast cancer MCF74 cells through induction of apoptosis or activation of p53, respectively (Albright et al. 2005; Kisztelinski et al. 2006). These studies suggest that methyl linoleate may be associated with the anti-tumor effects of Pe-W and Pe-C. However, other two major constituents in Pe-W and Pe-C are much different, 11-octadecenoic acid methyl ester (6.95\% VS $0.73 \%)$ and methyl oleate (0\% VS 15.23\%). Moreover, seven components including hexadecanoic acid, hexadecanoic acid, 2-hydroxy-, methyl ester, 12-methyl-E,E-2,13-octadecadien-1-ol, Z,E-3,13Octadecadien-1-ol, (22Z)-Cholesta-5,7,22 -trien-3-ol, desmosterol, ergosterol were found in Pe$\mathrm{W}$ but not in Pe-C. Some of them may have anti-tumor activity, such as ergosterol, which can reduce the breast cancer cell viability through induction of apoptosis and up-regulation of Foxo3 expression ( $\mathrm{Li}$ et al. 2015). The difference of components might cause the different antitumor activities of Pe-W and Pe-C. Therefore, it is worth further isolating and identifying the constituents that cause the different antitumor activities between wild and cultivated $P$. ferulae.

Our previous study showed that PFEE-C could inhibit the growth of tumor cells through induction of apoptosis (Wang et al. 2014). Similarly, PFEE-W/C and their sub-fractions significantly induced apoptosis of HeLa cells. Furthermore, ROS production induced by Ea-W and Ea-C partially caused apoptosis. However, ROS production showed dynamically changes upon Ea-W and Ea-C treatment, which might be correlated with their antioxidant activities. The possible reason is that some components in Ea-W and Ea-C quickly induced ROS production during the first $2 \mathrm{~h}$ and gradually scavenged by other components in Ea-W and Ea-C from 8 to $24 \mathrm{~h}$. Finally, ROS production reerupted at $48 \mathrm{~h}$ due to the progress of apoptosis in cells. 
294

295

296

297

298

299

300

301

302

303

304

305

306

307

308

309

310

311

312

313

314

315

316

317

318

319

\section{CONCLUSION}

These results indicated that the different extracts of wild and cultivated $P$. ferulae possessed antioxidant and antitumor activities. Although there are some differences in antioxidant and antitumor activities, cultivated $P$. ferulae could replace wild one to a great extent. $P$. ferulae could be used to develop functional food with antioxidant and antitumor activities.

\section{Author Contributions}

Yi Yang, Changshuang Fu, Fangfang Zhou and Xiaoyu Luo performed experiments. Yi Yang, Xiaoqin Li and Jinyu Li analyzed data and prepared figures. Jun Zhao, Jiang He and Jinyao Li designed the project. Jinyu Li and Jinyao Li wrote the manuscript.

\section{REFERENCES}

Alam N, Yoon KN, Lee JS, Cho HJ, and Lee TS. 2012. Consequence of the antioxidant activities and tyrosinase inhibitory effects of various extracts from the fruiting bodies of Pleurotus ferulae. Saudi J Biol Sci 19:111-118.

Albright, C. D., Klem, E., Shah, A. A., Gallagher, P. 2005. Breast cancer cell-targeted oxidative stress: enhancement of cancer cell uptake of conjugated linoleic acid, activation of $p 53$, and inhibition of proliferation. Experimental and molecular pathology 79: 118-125.

Bhattacharya, A., Banu, J., Rahman, M., Causey, J., \& Fernandes, G. 2006. Biological effects of conjugated linoleic acids in health and disease. The Journal of nutritional biochemistry 17: 789-810.

Chang JY, Senan S, Paul MA, Mehran RJ, Louie AV, Balter P, Groen HJ, McRae SE, Widder J, Feng L, van den Borne BE, Munsell MF, Hurkmans C, Berry DA, van Werkhoven E, Kresl JJ, Dingemans AM, Dawood O, Haasbeek CJ, Carpenter LS, De Jaeger K, Komaki R, Slotman BJ, Smit EF, and Roth JA. 2015. Stereotactic ablative radiotherapy versus lobectomy for operable stage I non-small-cell lung cancer: a pooled analysis of two randomised trials. Lancet Oncol 16:630-637. 
320

321

322

323

324

325

326

327

328

329

330

331

332

333

334

335

336

337

338

339

340

341

342

Chen W, Zheng R, Baade PD, Zhang S, Zeng H, Bray F, Jemal A, Yu XQ, and He J. 2016. Cancer statistics in China, 2015. CA Cancer J Clin 66:115-132.

Choi D, Piao YL, Yu SJ, Lee YW, Lim DH, Chang YC, Park SS, Lee MK, Cha WS, You DS, and Cho H. 2016. Antihyperglycemic and antioxidant activities of polysaccharide produced from pleurotus ferulae, in streptozotocin-induced diabetic rats. Korean J Orean Chem Eng 33:1872-1882.

Choi DB, Cha WS, Kang SH, and Lee BR. 2004. Effect of Pleurotus ferulae extracts on viability of human lung cancer and cervical cancer cell lines. Biothchnol Bioproc E 9:356-361.

Choi JH, Kim DW, Kim S and Kim SJ. 2017. Purification and partial characterization of a fibrinolytic enzyme from the fruiting body of the medicinal and edible mushroom Pleurotus ferulae. Prep Biochem Biotechnol 47:539-546.

Dubois M, Gilles KA, Hamilton JK, Rebers PA, and Smith F. 1956. Colorimetric method for determination of sugars and related substances. Analytical Chemistry 28:350-356.

Eberhardt WE, Pöttgen C, Gauler TC, Friedel G, Veit S, Heinrich V, Welter S, Budach W, Spengler W, Kimmich M, Fischer B, Schmidberger H, De Ruysscher D, Belka C, Cordes S, Hepp R, Lütke-Brintrup D, Lehmann N, Schuler M, Jöckel KH, Stamatis G, and Stuschke M. 2015. Phase III study of surgery versus definitive concurrent chemoradiotherapy boost in patients with resectable stage IIIA(N2) and selected IIIB non-small-cell lung cancer after induction chemotherapy and concurrent chemoradiotherapy (ESPATUE). J Clin Oncol 33:4194-4201.

Frenkel M, Ben-Arye E, Baldwin CD, and Sierpina V. 2005. Approach to communicating with patients about the use of nutritional supplements in cancer care. South Med J 98:289-294.

Global Burden of Disease Cancer Collaboration, Fitzmaurice C, Allen C, Barber RM, Barregard L, Bhutta ZA, Brenner H, Dicker DJ, Chimed-Orchir O, Dandona R, and Dandona L. 2017. Global, regional, and national cancer incidence, mortality, years of life lost, years lived with disability, and disability-adjusted life-years for 32 cancer groups, 1990 to 2015: a systematic analysis for the global burden of disease study. JAMA Oncol 3:524-548. 
347 Kalyoncu F, Oskay M, Sağlam H, Erdoğan TF, and Tamer AU. 2010. Antimicrobial and antioxidant activities of mycelia of 10 wild mushroom species. J Med Food 13:415-419.

349

350

351

352

353

354

355

356

357

358

359

360

361

362

363

364

365

366

367

368

369

370

371

372

373

Kisztelinski, D., Alink, G. M., Rietjens, I. M., Bielecki, S., Tramper, J., Martens, D. E. 2006. Application of a continuous bioreactor cascade to study the effect of linoleic acid on hybridoma cell physiology. Biotechnology and bioengineering 95: 370-383.

Lee IS, Ryoo IJ, Kwon KY, Ahn JS and Yoo ID. 2011. Pleurone, a novel human neutrophil elastase inhibitor from the fruiting bodies of the mushroom Pleurotus eryngii var. ferulae. J Antibiot (Tokyo) 64:587-589.

Le Tourneau C, Delord JP, Gonçalves A, Gavoille C, Dubot C, Isambert N, Campone M, Trédan O, Massiani MA, Mauborgne C, Armanet S, Servant N, Bièche I, Bernard V, Gentien D, Jezequel P, Attignon V, Boyault S, Vincent-Salomon A, Servois V, Sablin MP, Kamal M, Paoletti X, and investigators. S. 2015. Molecularly targeted therapy based on tumour molecular profiling versus conventional therapy for advanced cancer (SHIVA): a multicentre, open-label, proof-of-concept, randomised, controlled phase 2 trial. Lancet Oncol 16:1324-1334.

Li J, Wang X, Wang W, Luo J, Aipire A, Li J, and Zhang F. 2015. Pleurotus ferulae water extract enhances the maturation and function of murine bone marrow-derived dendritic cells through TLR4 signaling pathway. Vaccine 33:1923-1933.

Li J, Yuan P, Wang X, Aipire A, Li M, Yang J, Tao H, Ying T, Fu C, Wei X, Zhang F, and Li J. 2017. Purification, characterization and bioactivities of polysaccharides from Pleurotus ferulae. Food Funct 8:1905-1914.

Li, X., Wu, Q., Xie, Y., Ding, Y., Du, W. W., Sdiri, M., Yang, B. B. 2015. Ergosterol purified from medicinal mushroom Amauroderma rude inhibits cancer growth in vitro and in vivo by up-regulating multiple tumor suppressors. Oncotarget 6: 17832 .

Molyneux P. 2004. The use of the stable free radical diphenylpicrylhydrazyl (DPPH) for estimating antioxidant activity. Songklanakarin J Sci Technol 26:211-219.

Perez EA, Romond EH, Suman VJ, Jeong JH, Sledge G, Geyer CEJ, Martino S, Rastogi P, 

JA, and Wolmark N. 2014. Trastuzumab plus adjuvant chemotherapy for human epidermal growth factor receptor 2-positive breast cancer: planned joint analysis of overall survival from NSABP B-31 and NCCTG N9831. J Clin Oncol 32:3744-3752.

Redza-Dutordoir M, and Averill-Bates DA. 2016. Activation of apoptosis signaling pathways by reactive oxygen species. Biochim Biophys Acta 1863:2977-2992.

380

381

382

383

384

385

386

387

388

389

390

391

392

393

394

395

396

397

398

399

400

River J, McKenzie H, Levy D, Pavlakis N, Back M, and Oh B. 2018. Convergent priorities and tensions: a qualitative study of the integration of complementary and alternative therapies with conventional cancer treatment. Support Care Cancer 26:1791-1797.

Swamy MK, Sinniah UR, and Akhtar MS. 2015. In Vitro pharmacological activities and GC-MS analysis of different solvent extracts of Lantana camara leaves collected from tropical region of Malaysia. Evid Based Complement Alternat Med 2015:506413.

Wanchai A, Armer JM, and Stewart BR. 2010. Complementary and alternative medicine use among women with breast cancer: a systematic review. Clin J Oncol Nurs 14:E45-55.

Wang W, Chen K, Liu Q, Johnston N, Ma Z, Zhang F, and Zheng X. 2014. Suppression of tumor growth by Pleurotus ferulae ethanol extract through induction of cell apoptosis, and inhibition of cell proliferation and migration. PLoS One 9:e102673.

Whelan, J. 2008. The health implications of changing linoleic acid intakes. Prostag Leukotr Ess 79:165-167.

Xu CJ, Wang YX, Niu BN, Liu B, Li YB, Wang XM and Lu SL. 2014. Isolation and characterization of a novel lectin with mitogenic activity from Pleurotus ferulae. Pak J Pharm Sci 27:983-989.

Yang Y, Yuan P, Wei X, Fu C, Li J, Wang W, Wang X, Li Y, Li J. 2018. Cultivated and wild Pleurotus ferulae ethanol extracts inhibit hepatocellular carcinoma cell growth via inducing endoplasmic reticulum stress- and mitochondria-dependent apoptosis. Sci Rep $8: 13984$.

Yildirim A, Mavi A, and Kara AA. 2001. Determination of antioxidant and antimicrobial 
401 activities of Rumex crispus L. extracts. J Agric Food Chem 49:4083-4089.

402 Yu F, Sheng J, Xu J, An X, and Hu Q. 2007. Antioxidant activities of crude tea polyphenols, 403 polysaccharides and proteins of selenium-enriched tea and regular green tea. Eur Food Res Technol 225:843-848. 


\section{Table $\mathbf{1}$ (on next page)}

The contents of polysaccharides, polyphenols and flavonoids in PFEE-W and PFEE-C and their sub-fractions.

Values in the column followed by a different letter superscript were significantly different $(p<0.05)$ and values had the same letters are not statistically significant $(p>0.05)$. 
1 Table 1. The contents of polysaccharides, polyphenols and flavonoids in PFEE-W and

2 PFEE-C and their sub-fractions.

\begin{tabular}{cccc}
\hline $\begin{array}{c}\text { Sample } \\
(100 \mathrm{mg} / \mathrm{ml})\end{array}$ & $\begin{array}{c}\text { Polysaccharides } \\
(\mathrm{mg} / \mathrm{ml})\end{array}$ & $\begin{array}{c}\text { Polyphenols } \\
(\mathrm{mg} / \mathrm{ml})\end{array}$ & $\begin{array}{c}\text { Flavonoids } \\
(\mathrm{mg} / \mathrm{ml})\end{array}$ \\
\hline PFEE-W & $38.46 \pm 1.005^{\mathrm{b}}$ & $0.256 \pm 0.011^{\mathrm{a}}$ & $1.202 \pm 0.022^{\mathrm{a}}$ \\
Pe-W & $9.764 \pm 0.618^{\mathrm{e}}$ & $0.099 \pm 0.005^{\mathrm{c}}$ & $0.206 \pm 0.002^{\mathrm{d}}$ \\
Ea-W & $20.36 \pm 0.520^{\mathrm{cd}}$ & $0.150 \pm 0.004^{\mathrm{b}}$ & $1.269 \pm 0.037^{\mathrm{a}}$ \\
Ba-W & $40.64 \pm 0.646^{\mathrm{b}}$ & $0.063 \pm 0.001^{\mathrm{c}}$ & $0.609 \pm 0.019^{\mathrm{c}}$ \\
PFEE-C & $54.87 \pm 0.840^{\mathrm{a}}$ & $0.250 \pm 0.017^{\mathrm{a}}$ & $1.04 \pm 0.018^{\mathrm{b}}$ \\
Pe-C & $20.84 \pm 1.011^{\mathrm{c}}$ & $0.211 \pm 0.010^{\mathrm{a}}$ & $0.176 \pm 0.006^{\mathrm{de}}$ \\
Ea-C & $16.14 \pm 0.906^{\mathrm{d}}$ & $0.063 \pm 0.006^{\mathrm{c}}$ & $0.566 \pm 0.015^{\mathrm{c}}$ \\
Ba-C & $38.51 \pm 1.143^{\mathrm{b}}$ & $0.009 \pm 0.001^{\mathrm{d}}$ & $0.100 \pm 0.002^{\mathrm{e}}$ \\
\hline
\end{tabular}

3 Values in the column followed by a different letter superscript were significantly different $(p<0.05)$ and values 4 had the same letters are not statistically significant $(p>0.05)$.

5

6 
Table 2 (on next page)

Chemical composition and contents of fatty acids of Pe-W and Pe-C. 
1 Table 2. Chemical composition and contents of fatty acids of Pe-W and Pe-C.

\begin{tabular}{|c|c|c|c|c|c|}
\hline \multirow[t]{2}{*}{ No. } & \multirow[t]{2}{*}{ Compounds } & \multicolumn{2}{|c|}{$\begin{array}{c}\text { Retention Time } \\
\text { (min) }\end{array}$} & \multicolumn{2}{|c|}{$\begin{array}{c}\text { Composition } \\
(\%)\end{array}$} \\
\hline & & $\mathrm{Pe}-\mathrm{W}$ & $\mathrm{Pe}-\mathrm{C}$ & $\mathrm{Pe}-\mathrm{W}$ & $\mathrm{Pe}-\mathrm{C}$ \\
\hline 1 & Methyl tetradecanoate & - & 21.46 & - & 0.39 \\
\hline 2 & Pentadecanoic acid, methyl ester & 26.60 & 26.09 & 0.76 & 0.73 \\
\hline 3 & 9-Hexadecenoic acid,methyl ester & - & 29.49 & - & 0.65 \\
\hline 4 & 7-Hexadecenoic acid,methyl ester & 30.03 & 29.96 & 0.24 & 0.16 \\
\hline 5 & Hexadecanoic acid, methyl ester & 31.29 & 30.87 & 10.44 & 14.32 \\
\hline 6 & Hexadecanoic acid & 33.03 & - & 4.10 & - \\
\hline 7 & Octadecanoic acid & 33.39 & - & 0.13 & - \\
\hline 8 & Hexadecanoic acid, 2-hydroxy-, methyl ester & 36.10 & - & 1.24 & - \\
\hline 9 & Myo-inositol, hexaacetate & - & 36.72 & - & 6.15 \\
\hline 10 & Methyl linoleate & 37.98 & 37.70 & 60.95 & 58.25 \\
\hline 11 & Methyl oleate & - & 37.97 & - & 15.23 \\
\hline 12 & 11-Octadecenoic acid, methyl ester & 38.25 & 38.06 & 6.95 & 0.73 \\
\hline 13 & 13-Octadecenoic acid, methyl ester & 38.44 & - & 0.83 & - \\
\hline 14 & Methyl stearate & 39.35 & 38.91 & 2.89 & 0.93 \\
\hline 15 & 12-Methyl-E,E-2,13-octadecadien-1-ol & 39.62 & - & 2.27 & - \\
\hline 16 & Z,E-3,13-Octadecadien-1-ol & 40.61 & - & 1.20 & - \\
\hline 17 & Methyl 6-cis,9-cis, 11-trans-octadecatrienoate & - & 42.51 & - & 0.24 \\
\hline 18 & 2-Methyl-E,E-3,13-octadecadien-1-ol & - & 43.03 & - & 0.22 \\
\hline 19 & Methyl 8,11,14,17-eicosatetraenoate & 43.48 & 43.46 & 0.64 & 0.20 \\
\hline 20 & cis-5,8,12-Eicosatrienoic acid, methyl ester & - & 43.58 & - & 0.22 \\
\hline 21 & 8,11-Eicosadienoic acid, methyl ester & - & 44.13 & - & 0.13 \\
\hline 22 & cis-11-Eicosenoic acid, methyl ester & - & 44.39 & - & 0.14 \\
\hline 23 & 13-Docosenoic acid, methyl ester, (Z)- & - & 48.75 & - & 0.10 \\
\hline 24 & Bis(2-ethylhexyl) phthalate & - & 49.00 & - & 0.11 \\
\hline 25 & Docosanoic acid, methyl ester & - & 49.19 & - & 0.08 \\
\hline 26 & Cyclopropaneoctanoic acid, 2-octyl-, methyl ester & 49.42 & 49.38 & 0.13 & 0.07 \\
\hline 27 & 11-Eicosenoic acid, methyl ester & - & 50.15 & - & 0.08 \\
\hline 28 & 15-Tetracosenoic acid, methyl ester, (Z)- & 52.02 & 51.69 & 0.35 & 0.46 \\
\hline 29 & Tetracosanoic acid, methyl ester & 52.51 & 52.17 & 0.22 & 0.18 \\
\hline 30 & Butanedioic acid, 2,3-bis(8-nonen-1-yl)-, dimethyl ester & - & 53.47 & - & 0.09 \\
\hline 31 & 12-Methyl-E,E-2,13-octadecadien-1-ol & 54.42 & - & 0.19 & - \\
\hline 32 & Methyl 2-hydroxy-tetracosanoate & 55.04 & - & 0.61 & - \\
\hline 33 & Methyl 17-hexacosenoate & - & 55.63 & - & 0.14 \\
\hline
\end{tabular}


(22Z)-Cholesta-5,7,22-trien-3-ol

$\begin{array}{llll}61.62 & - & 1.50 & - \\ 63.32 & - & 2.63 & - \\ 64.00 & - & 1.73 & -\end{array}$

2

Desmosterol

Ergosterol

64.00

1.73 


\section{Figure 1}

The antioxidant activities of PFEE-W/C and their sub-fractions.

(A) DPPH scavenging activities. (B) Total reducing power. Vc was used as positive control. 
A
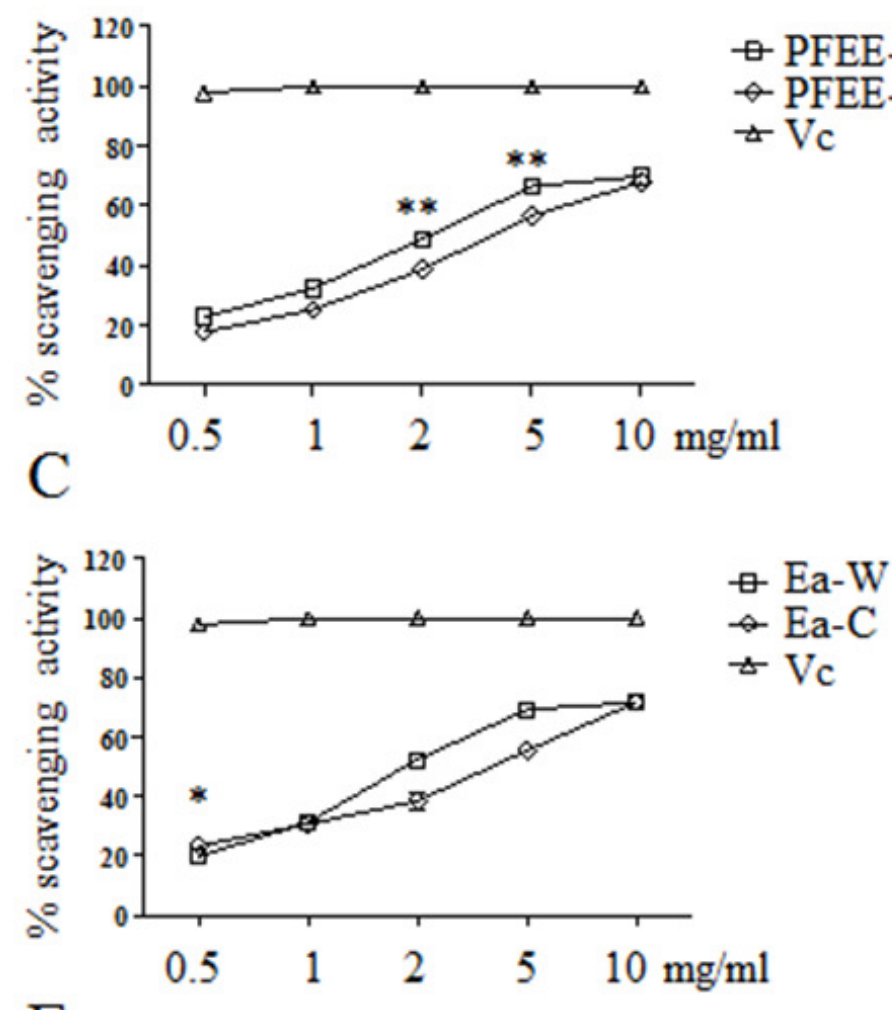

E
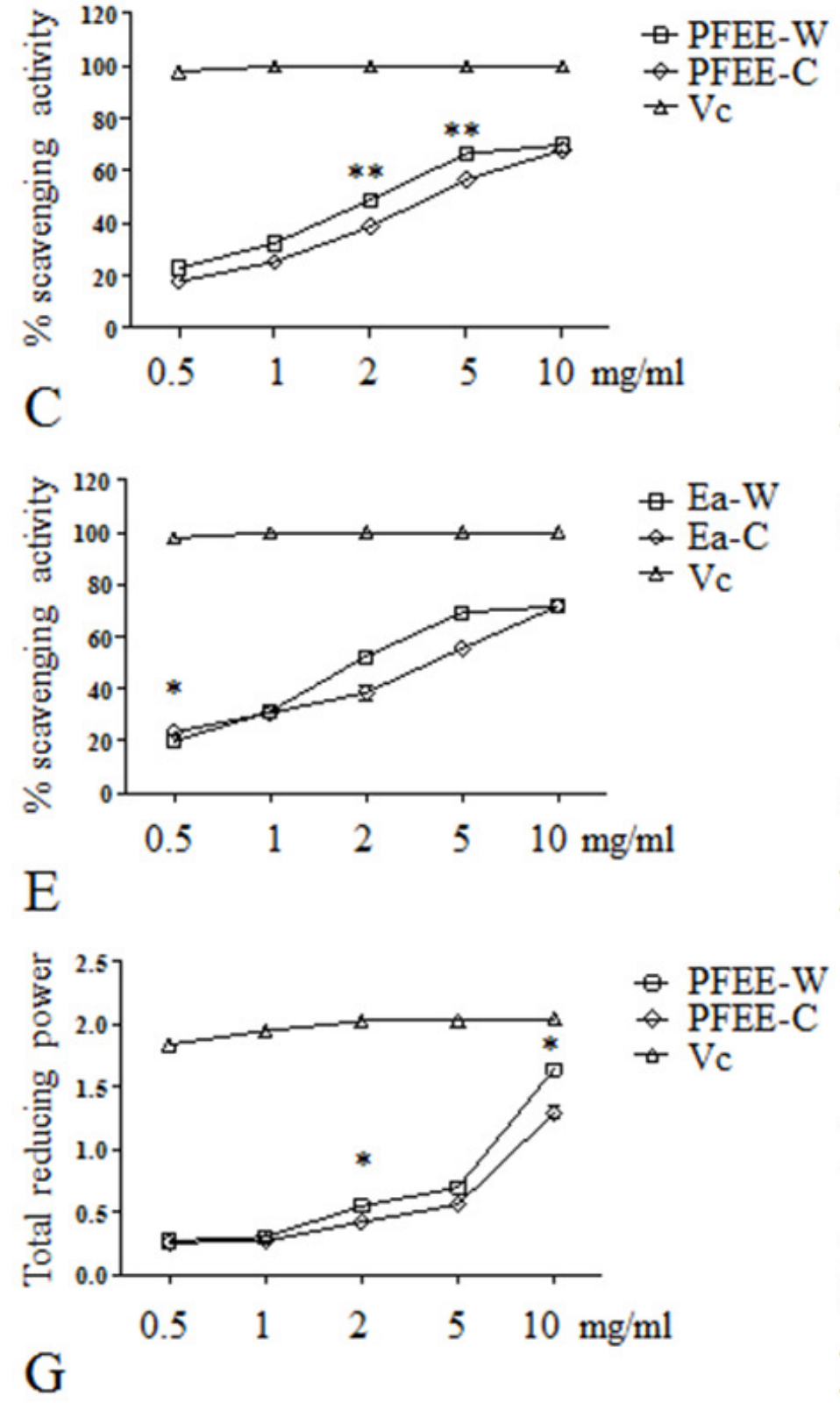

B
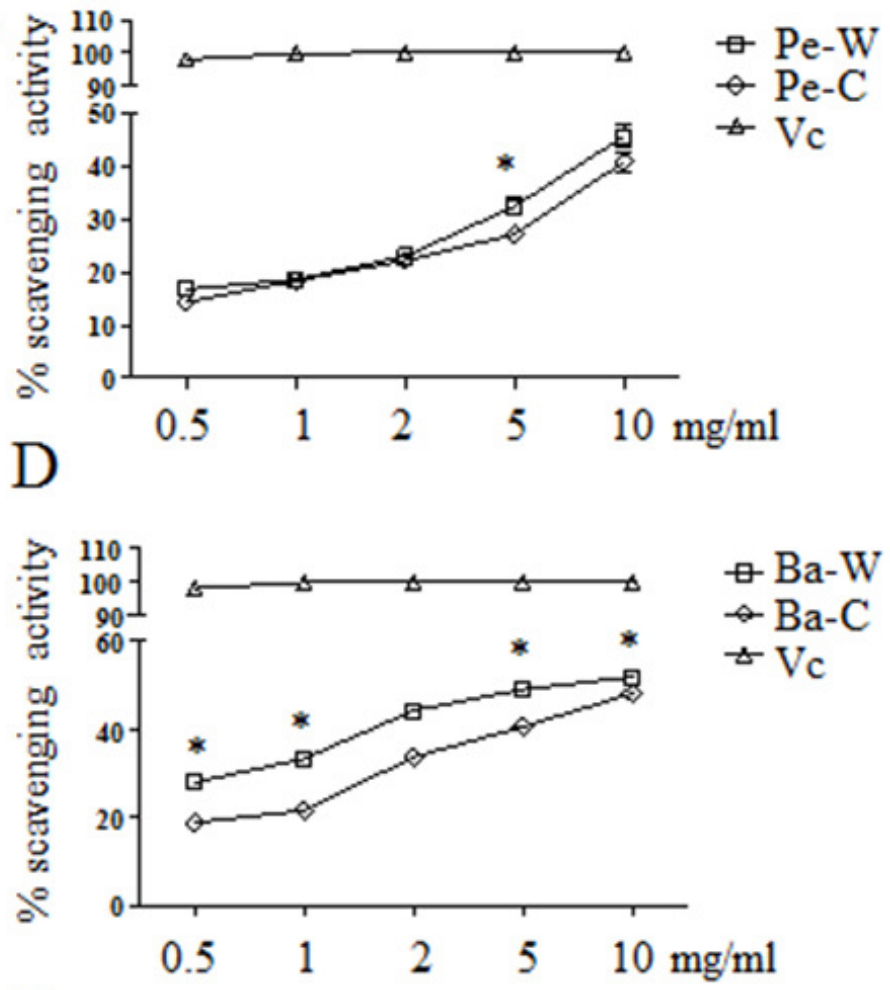

F

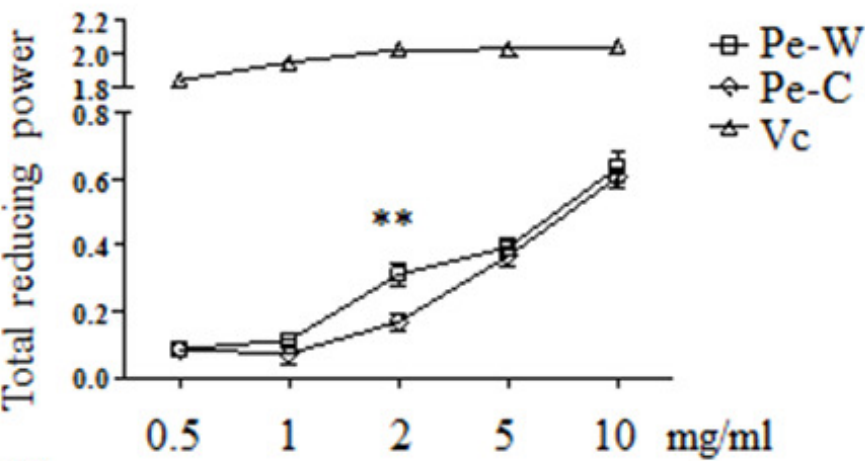

$\mathrm{H}$

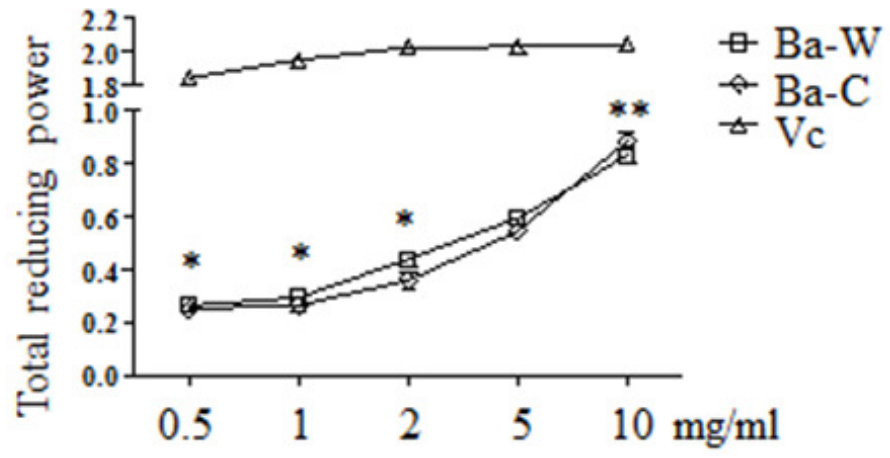


Figure 2

Effect of PFEE-W/C and their sub-fractions on the growth of tumor cells.

The viability of B16 (A), Eca-109 (B), BGC823 (C) and HeLa (D) cells after treatment with PFEE-W/C and their sub-fractions for $24 \mathrm{~h}$. Data are from 3 independent experiments and analyzed by ANOVA. $* p<0.05 ; * *<<0.01 ; * * p<0.001$ compared to untreated group. The two-tailed paired t test was used to compare wild and cultivated P. ferulae extracts. $* p<$ $0.05 ; * * p<0.01 ; * * * p<0.001$. 

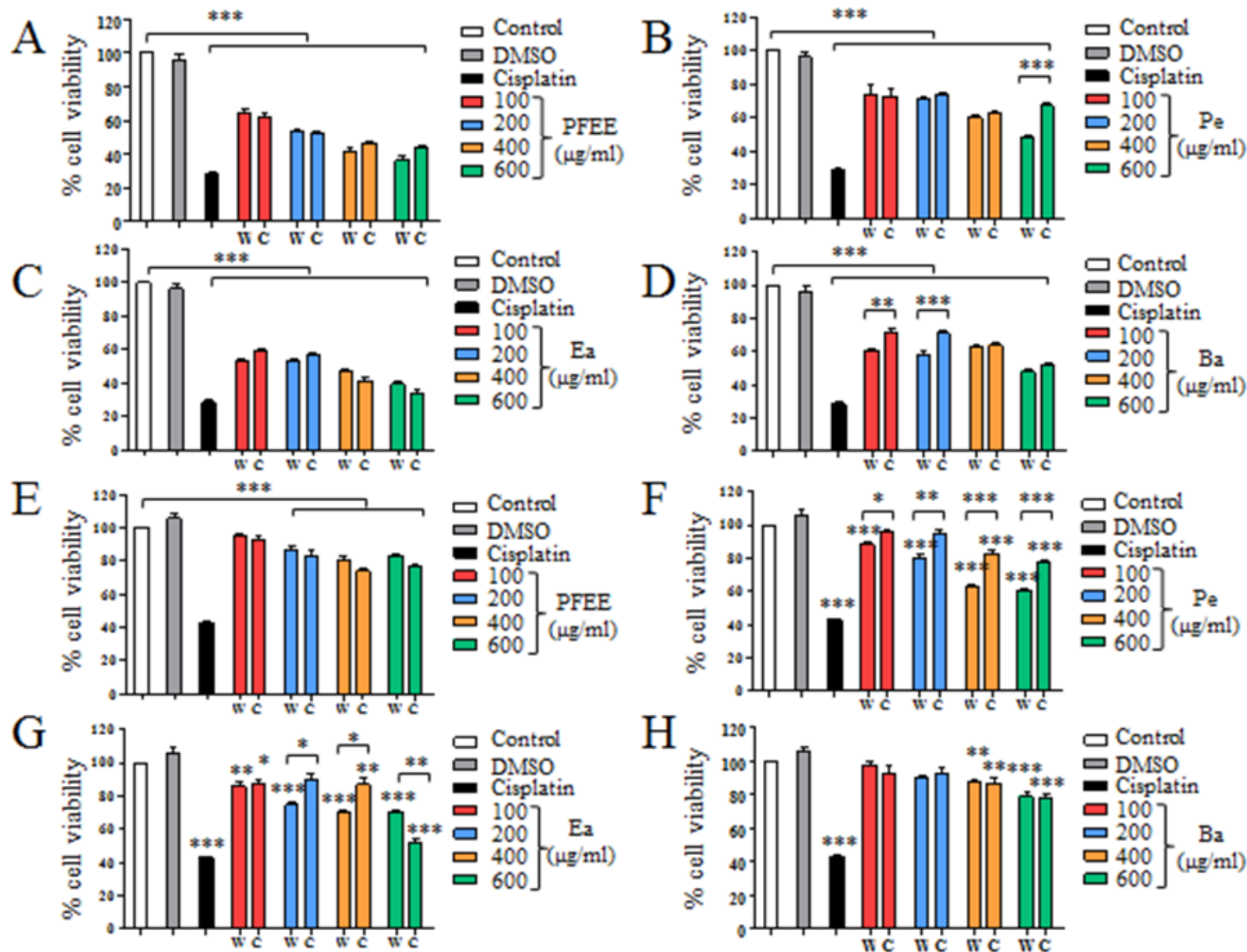

F

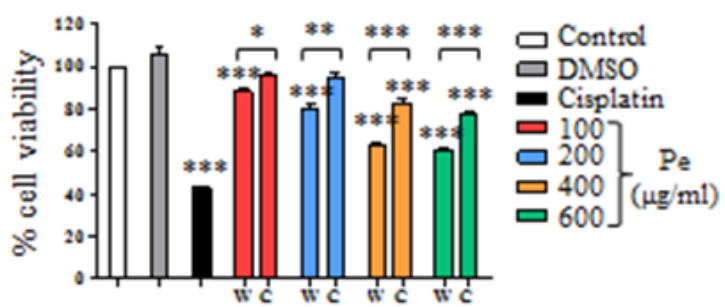

$\mathrm{H}$

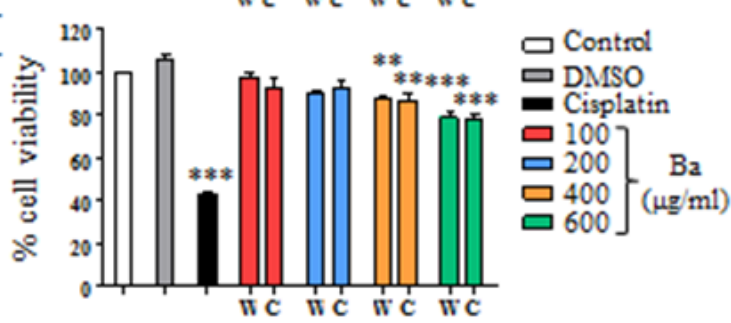

I

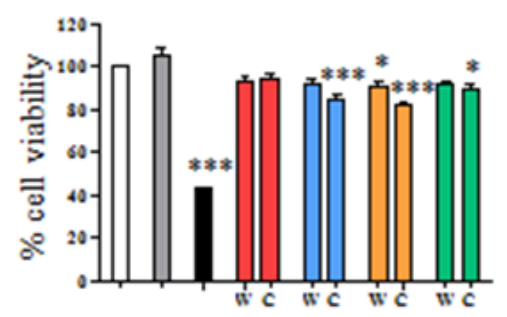

- Control

믈 Displatin

口 1007

口 200 PFEE

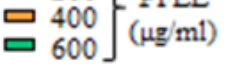

K
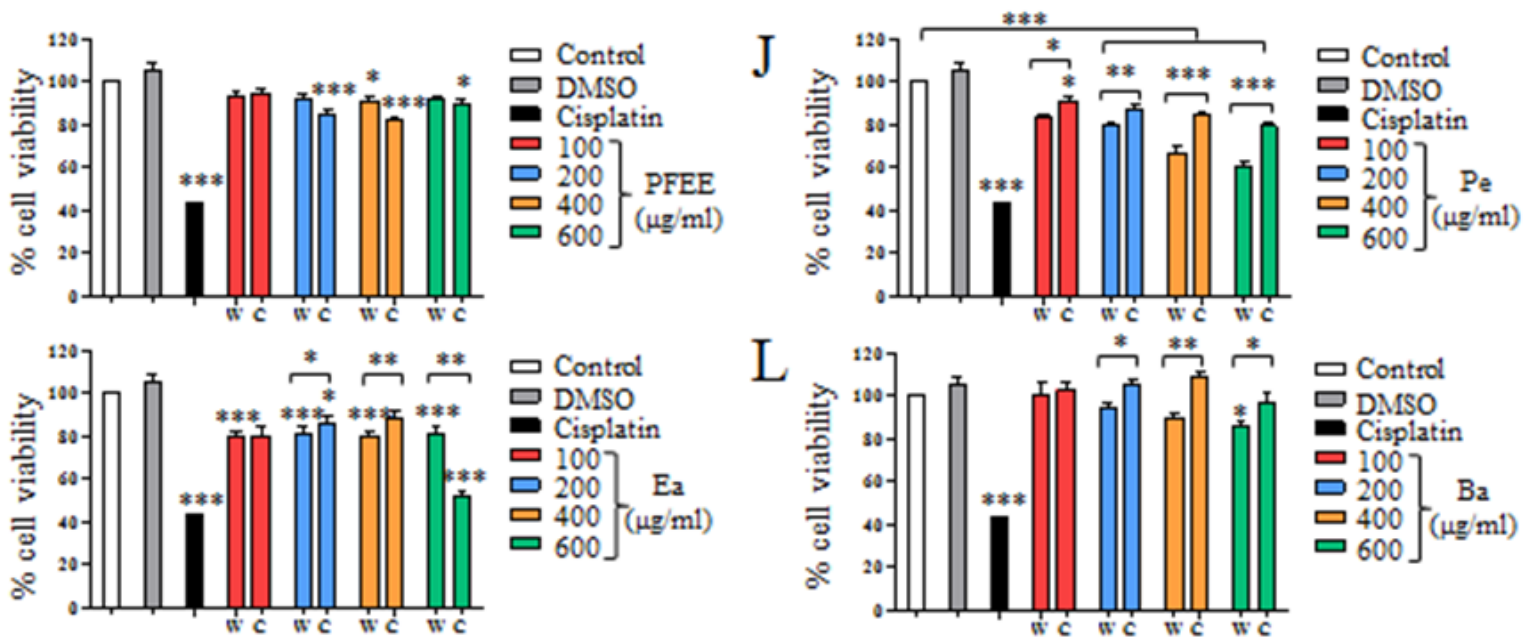

L

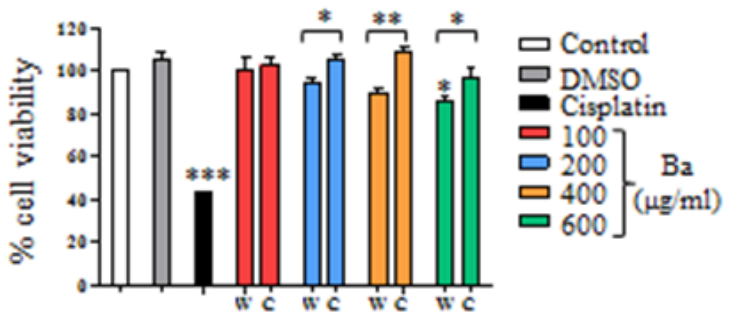

L

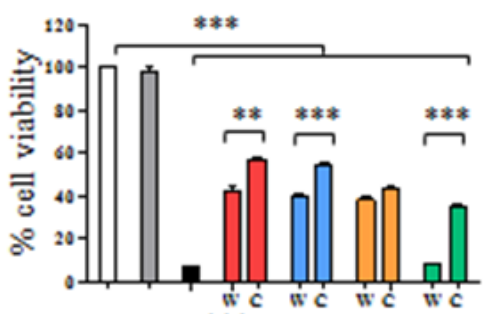

口 Control

- Cisplatin

$\square \begin{aligned} & 100 \\ & 200\end{aligned}$

DFE

므 600$]^{\circ}(\mu \mathrm{g} / \mathrm{ml})$

$\mathrm{N}$

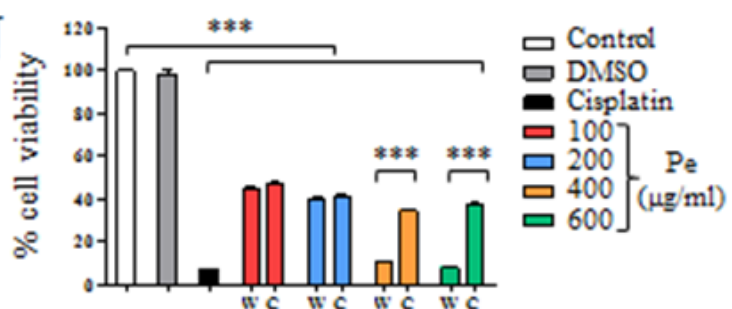

$\mathrm{O}$
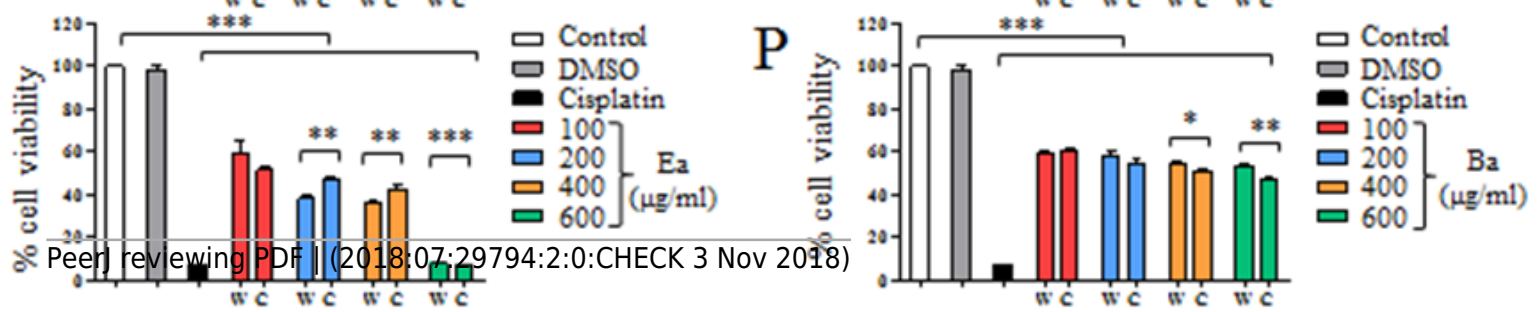


\section{Figure 3}

The apoptosis of HeLa cells induced by PFEE-W/C and their sub-fractions.

$400 \mu \mathrm{g} / \mathrm{ml}$ of PFEE-W/C and their sub-fractions were used to treat HeLa cells for $24 \mathrm{~h}$. (A) HeLa cells were stained by Annexin V/PI and analyzed by flow cytometry. The individual dot plots were shown in left panels and the summary data were shown in right panels. Data are from 3 independent experiments and analyzed by ANOVA. * $p<0.05$; ** $p<0.01$; *** $p<$ 0.001 compared to untreated group. The two-tailed paired t test was used to compare wild and cultivated $P$. ferulae extracts, $* p<0.05$; $* *<0.01$. (B) The nuclear morphology of HeLa cells. HeLa cells were stained with Hoechst 33342 and observed by inverted fluorescence microscopy. The arrows indicated the chromosomal condensation. 

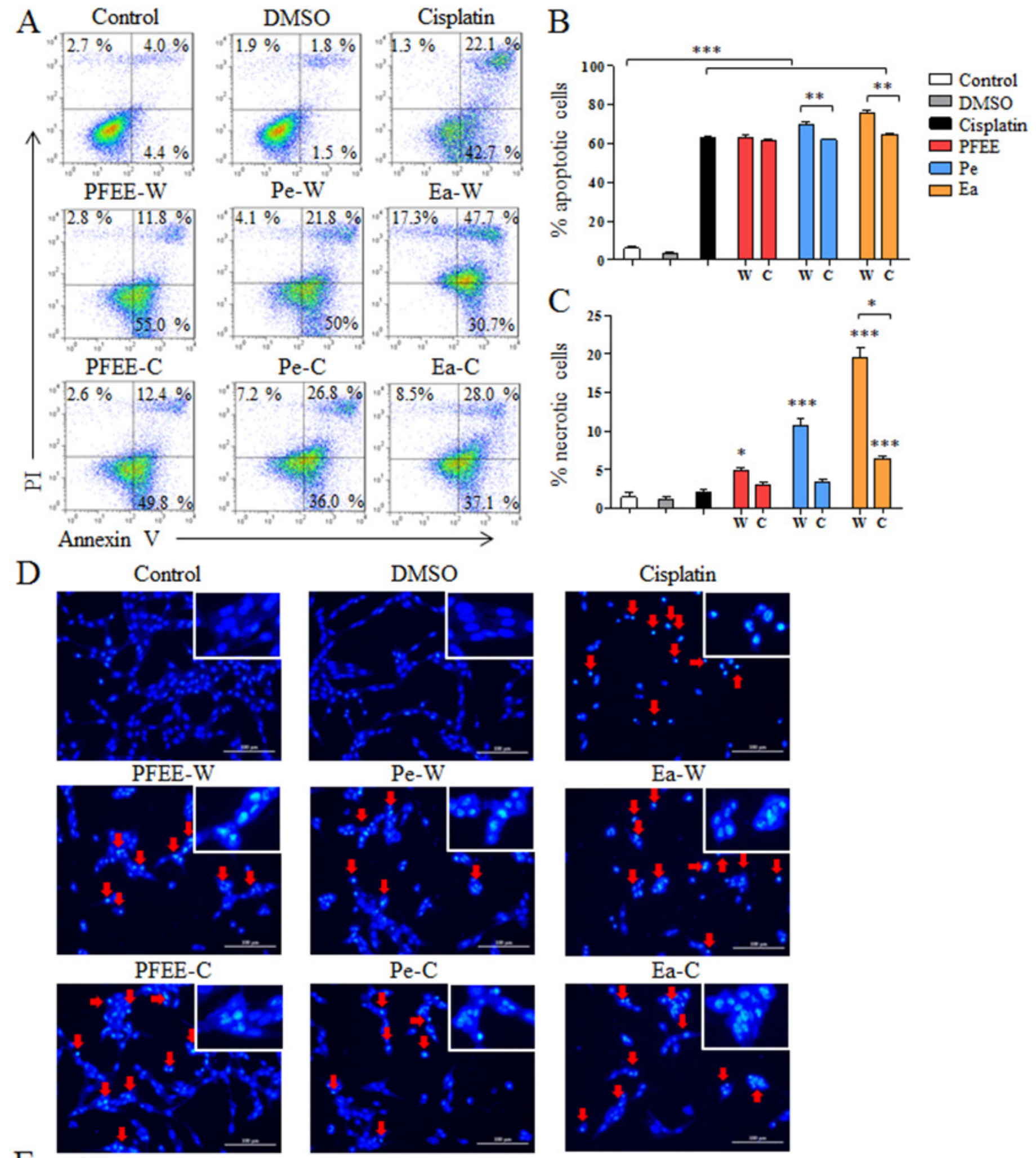

E
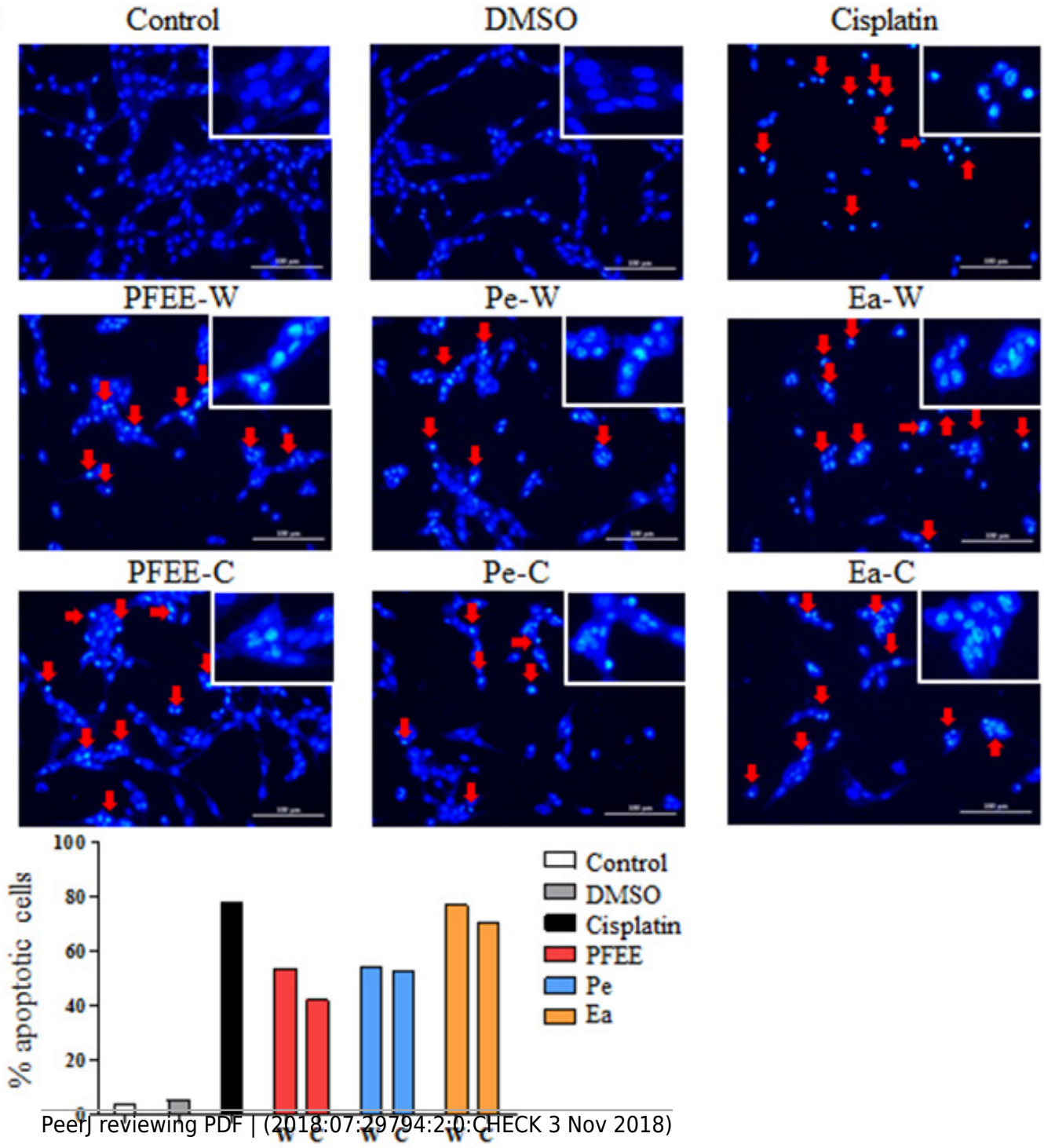


\section{Figure 4}

Intracellular ROS production and its role in the induction of apoptosis upon Ea-W and Ea-C treatment.

(A) Intracellular ROS production in HeLa cells treated with $400 \mu \mathrm{g} / \mathrm{ml}$ of Ea-W and Ea-C. After treatment for 2, 8, 12, 24 and $48 \mathrm{~h}$, cells were stained with fluorescent probe DCFH-DA and analyzed by flow cytometry. (B) The role of ROS in the induction of apoptosis. HeLa cells were pretreated with $10 \mathrm{mM} \mathrm{NAC}$ for $2 \mathrm{~h}$ and treated with Ea-W and Ea-C for $24 \mathrm{~h}$. After staining with Annexin $\mathrm{V} / \mathrm{Pl}$, samples were analyzed by flow cytometry. Data are from 3 independent experiments and analyzed by ANOVA. $* p<0.05$; $* *<0.01 ; * * *<0.001$ compared to untreated group. The two-tailed paired $t$ test was used to compare wild and cultivated P. ferulae extracts. $* p<0.05 ; * * p<0.01 ; * * * p<0.001$. 
A

ن

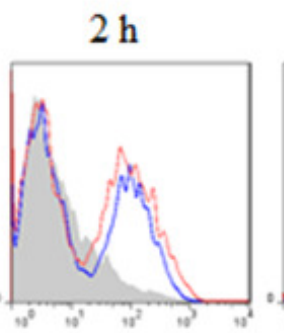

$8 \mathrm{~h}$

$12 \mathrm{~h}$

$24 \mathrm{~h}$ $48 \mathrm{~h}$

FL-1
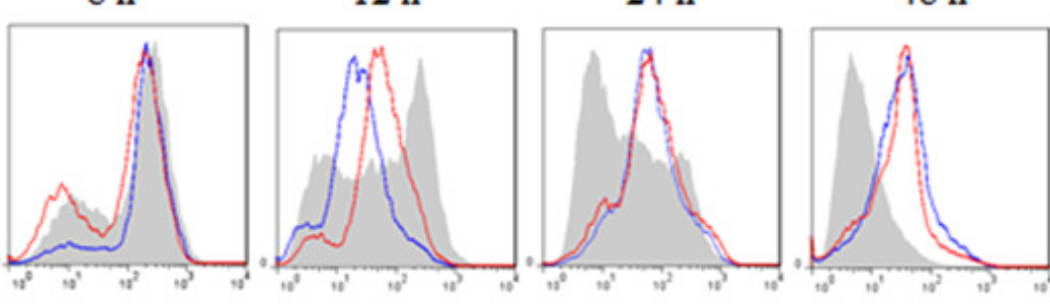

Control

$400 \mu \mathrm{g} / \mathrm{ml} \mathrm{Ea}-\mathrm{W}$

$400 \mu \mathrm{g} / \mathrm{ml} \mathrm{Ea}-\mathrm{C}$

B

$2 \mathrm{~h}$

$8 \mathrm{~h}$

$12 \mathrm{~h}$

$24 \mathrm{~h}$

$48 \mathrm{~h}$

Control Ea-W Ea-C

C
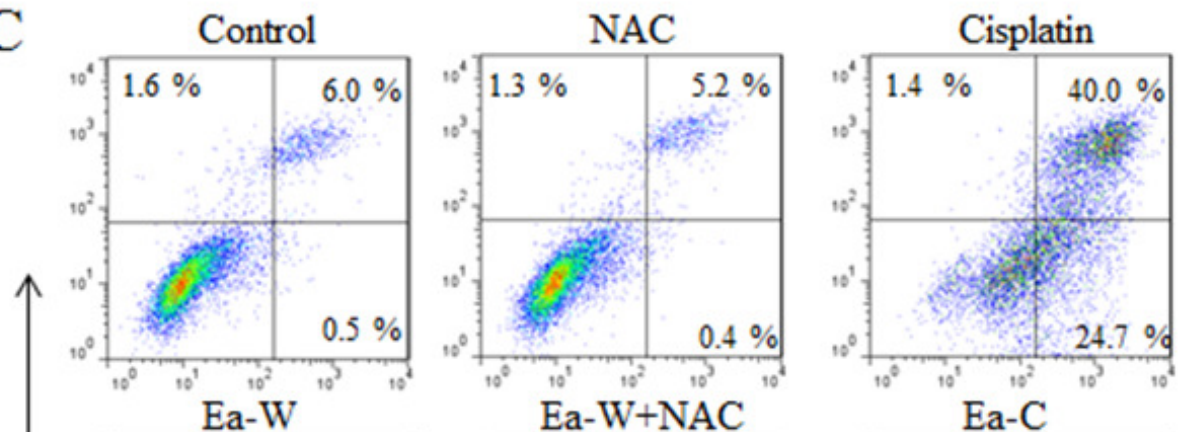

Cisplatin $+\mathrm{NAC}$
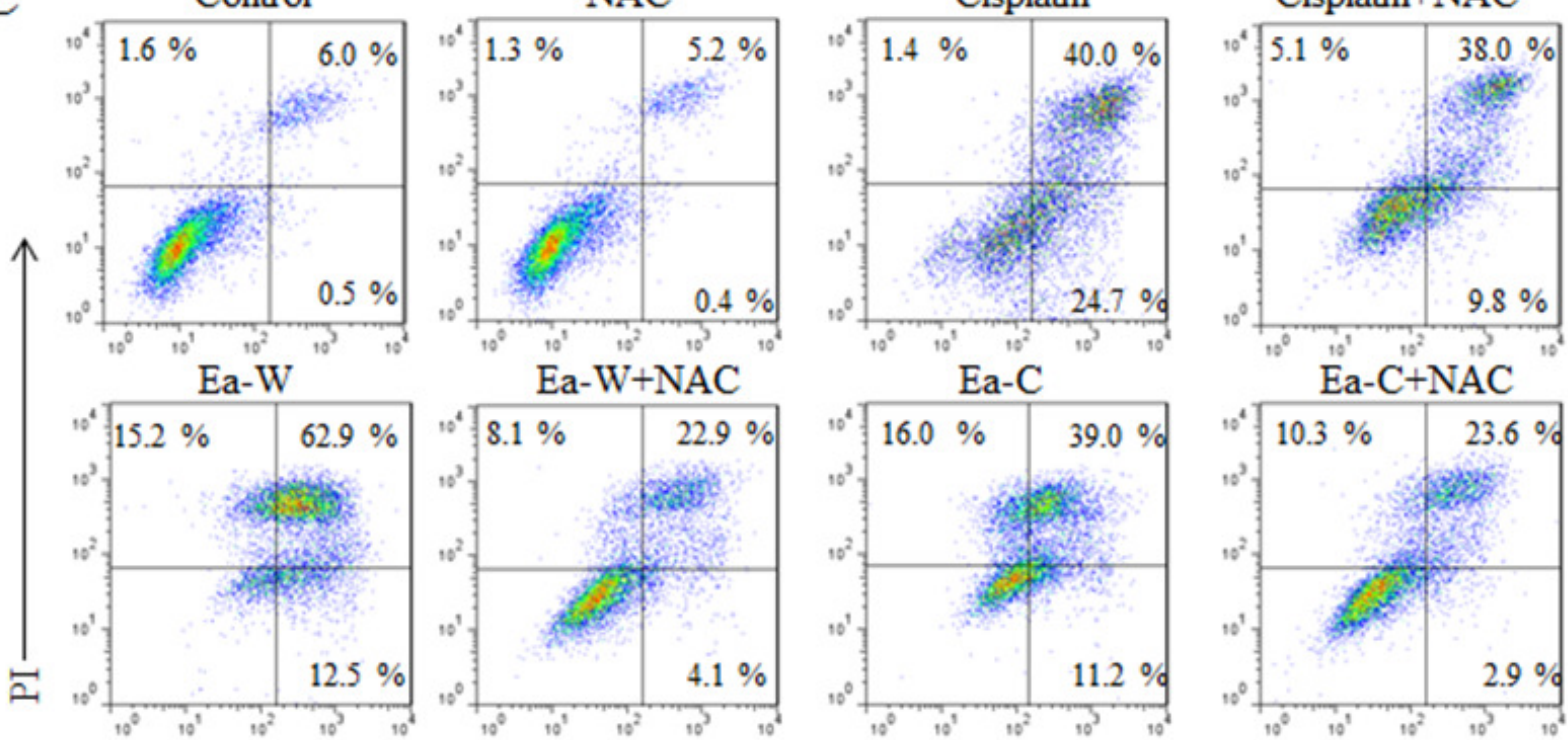

D
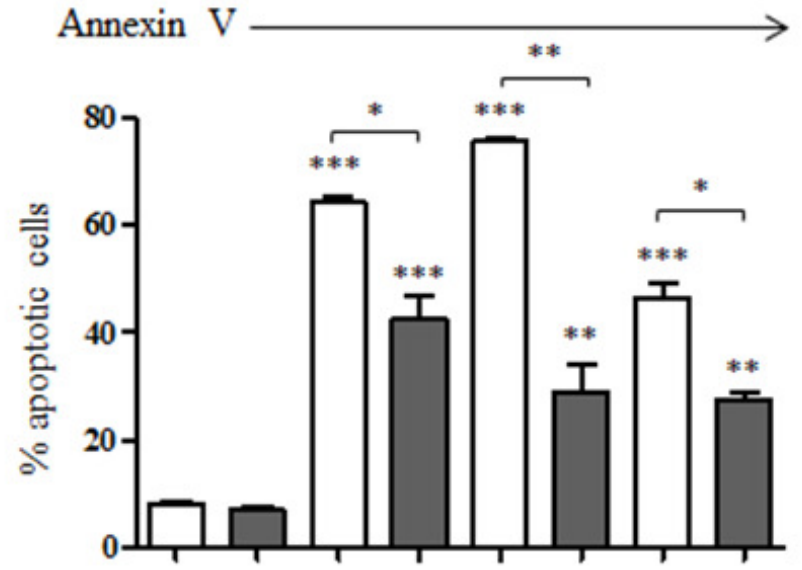

Cisplatin

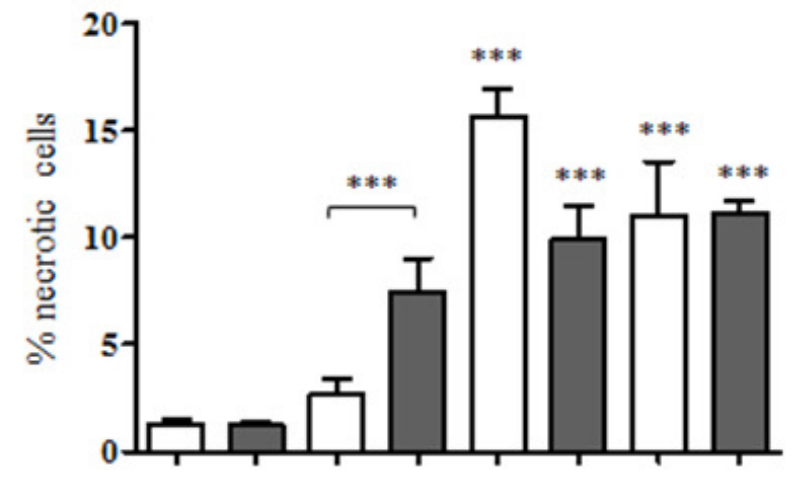

Ea-W

$\mathrm{Ea}-\mathrm{C}-{ }_{-}-{ }_{-}++$

Cisplatin

Ea-W

NAC 